\title{
Antioxidative Constituents of the Aerial Parts of Galium spurium
}

\author{
Seokwon Yang, Saerom Park, Dalrae Ahn, Jae Heon Yang and Dae Keun Kim* \\ College of Pharmacy, Woosuk University, Jeonju 565-701, Republic of Korea
}

\begin{abstract}
As part of an ongoing search for natural plants with antioxidant compounds by measuring the radical scavenging effect on 1,1-diphenyl- 2-picrylhydrazyl (DPPH), a total extract of the twigs of Galium spurium L. (Rubiaceae) was found to show potent antioxidant activity. Subsequent activity-guided fractionation of the methanolic extract led to the isolation of nine compounds, asperulosidic acid methyl ester (1), asperuloside (2), caffeic acid (3), kaempferol-3-O-L-rhamnopyranoside (4), quercetin-3-O-[ $\alpha$-Lrhamnopyranosyl( $1 \rightarrow 6)$ - $\beta$-D-glucopyranoside] (5), isorhamnetin-3-O-glucopyranoside (6), quercetin-3-O- $\alpha$-L-rhamnopyranoside (7), kaempferol-3-O-[ $\alpha$-L-rhamnopyranosyl( $1 \rightarrow 6)-\beta-D$-glucopyranoside] (8), and quercetin (9). Their structures were elucidated by spectroscopic studies. Compounds 1, 3-8 were isolated for the first time from this plant. Among them, compounds 3 and 9 showed the significant radical scavenging effects on DPPH, and compounds 3 and 7 showed the potent riboflavin originated superoxide quenching activities.
\end{abstract}

Key Words: Galium spurium L., Rubiaceae, Antioxidant activity, DPPH radical, Superoxide quenching activity

\section{INTRODUCTION}

Reactive oxygen species (ROS), in the form of superoxide anion $\left(\mathrm{O}_{2}^{-}\right)$, hydroxyl radical $(\cdot \mathrm{OH})$ and hydrogen peroxide $\left(\mathrm{H}_{2} \mathrm{O}_{2}\right)$, are generated in living organisms through many pathways (Chung et al., 2005). An imbalance between production of ROS and their elimination in the organisms cause oxidative stress (Monika et al., 2010). Oxidative stress has been implicated as a possible factor in the etiology of several human diseases, including cancer, cardiovascular disease, Alzheimer's disease and aging (Suganya et al., 2007). Antioxidants are the important defense factors against oxidative stress caused by ROS. However, the use of synthetic antioxidant components, such as butylated hydroxyanisole (BHA) and butylated hydroxytoluene (BHT), has been limited because of their possible toxic and carcinogenic effects (Branen, 1975). Thus, there is a growing interest in finding natural herbal plants with low in toxicity and high in radical scavenging activity (Branen, 1975). In the course of screening for antioxidant from Korean natural plants by measuring the radical scavenging effect on 1,1-diphenyl-2-picrylhydrazyl (DPPH), a total extract of the Galium spurium L. (Rubiaceae) was found to show a potent antioxidant activity. G. spurium is annual or biannual plant. Phytochemical studies on the genus have shown it to be chemically diverse, yielding among others, triterpenoid saponins, iridoid

www.biomolther.org

Open Access DOI: 10.4062/biomolther.2011.19.3.336

pISSN: 1976-9148 elSSN: 2005-4483

Copyright $\odot 2011$ The Korean Society of Applied Pharmacology glucosides (Salvatore et al., 2000). Some iridoids (Deliorman et al., 2001), anthraquinones (Koyama et al., 1993) and flavonoids (Cai et al., 2009) were analyzed from G. spurium. Its aerial parts have been used for the treatment of the bones and sinews pain and hematuria. Crude extract of G. spurium was also used as a anticancer agent in folk medicine. It has been reported to have immunostimulant and anti-tumor activity (Yoon et al., 2005). However, information concerning the antioxidant activity of $G$. spurium is unavailable. This paper deals with the isolation and structural characterization of these compounds and their scavenging activity of the stable DPPH free radical and superoxide quenching activities.

\section{MATERIALS AND METHODS}

\section{General experimental procedures}

NMR spectra were determined on a JEOL JMN-EX 400 spectrometer. Sephadex LH-20 was used for column chromatography (25-100 $\mu$ m; Fluka, Buchs, Switzeland). Prep-HPLC was carried out on a Jaigel GS310 column (Tokyo, Japan). TLC was carried out on Merck (Darmstadt, Germany) precoated silica gel $F_{254}$ plates, and silica gel for column chromatography was Kiesel gel 60 (230-400 mesh, Merck). Spots were detected under UV and by spraying with $10 \% \mathrm{H}_{2} \mathrm{SO}_{4}$ in

Received Mar 31, 2011 Revised May 26, 2010 Accepted Jun 3, 2011

\section{* Corresponding Author}

E-mail: dkkim@mail.woosuk.ac.kr

Tel: +82-63-290-1574, Fax: +82-63-290-1812 
ethanol followed by heating at $100-120^{\circ} \mathrm{C}$ for $3 \mathrm{~min}$. All other chemicals and solvents were of analytical grade and used without further purification. Ascorbic acid, butylated hydroxyanisole (BHA) and 1,1-diphenyl-2-picrylhydrazyl (DPPH) were obtained from Sigma Chemical Co. (St. Louis, USA).

\section{Plant materials}

The aerial parts of $G$. spurium were collected and air-dried in August 2010 at Wanju, Jeonbuk, Korea. A voucher specimen was deposited in the herbarium of College of Pharmacy, Woosuk University (WSU-10-012).

\section{Extraction and isolation}

The shade dried plant material $(1.8 \mathrm{~kg})$ was extracted three times with $\mathrm{MeOH}$ at $50^{\circ} \mathrm{C}$ and filtered. The extracts were combined and evaporated in vacuo at $50^{\circ} \mathrm{C}$. The resultant methanolic extract $(306 \mathrm{~g})$ was subjected to successive solvent partitioning to give $n$-hexane $(50.4 \mathrm{~g})$, methylene chloride (1.9 $\mathrm{g})$, ethyl acetate $(3.0 \mathrm{~g}), n-\mathrm{BuOH}(30.0 \mathrm{~g})$ and $\mathrm{H}_{2} \mathrm{O}$ soluble fractions. Each fraction was tested for the radical scavenging effect on 1,1-diphenyl-2-picrylhydrazyl (DPPH). Among these fractions, the ethyl acetate fraction showed the most significant free radical scavenging effect on DPPH (Fig. 1). The ethyl acetate soluble extract was subjected to chromatography on a Sephadex $\mathrm{LH}-20$ column and give eight fractions (E1-E8). Fraction E2 (980 mg) was chromatographed on silica gel column chromatography $\left(\mathrm{CHCl}_{3}-\mathrm{MeOH}-\mathrm{H}_{2} \mathrm{O}, 60: 10: 1\right)$ to give eight subfractions (E21-E28). Subfraction E28 (150 mg) was further chromatographed on a Sephadex LH-20 column $(\mathrm{MeOH})$ and purified on a JAI-GS310 cloumn $(\mathrm{MeOH})$ to give compound $1(13 \mathrm{mg})$. Fraction E3 $(490 \mathrm{mg})$ was chromatographed on silica gel column chromatography $\left(\mathrm{CHCl}_{3}-\mathrm{MeOH}-\right.$ $\left.\mathrm{H}_{2} \mathrm{O}, 50: 10: 1\right)$ to give three subfractions (E31-E33). Subfraction E32 (190 mg) was further chromatographed on silica gel column chromatography $\left(\mathrm{CHCl}_{3}-\mathrm{MeOH}-\mathrm{H}_{2} \mathrm{O}, 50: 10: 1\right)$ and purified on a JAI-GS310 cloumn (MeOH) to give compound 2 (15

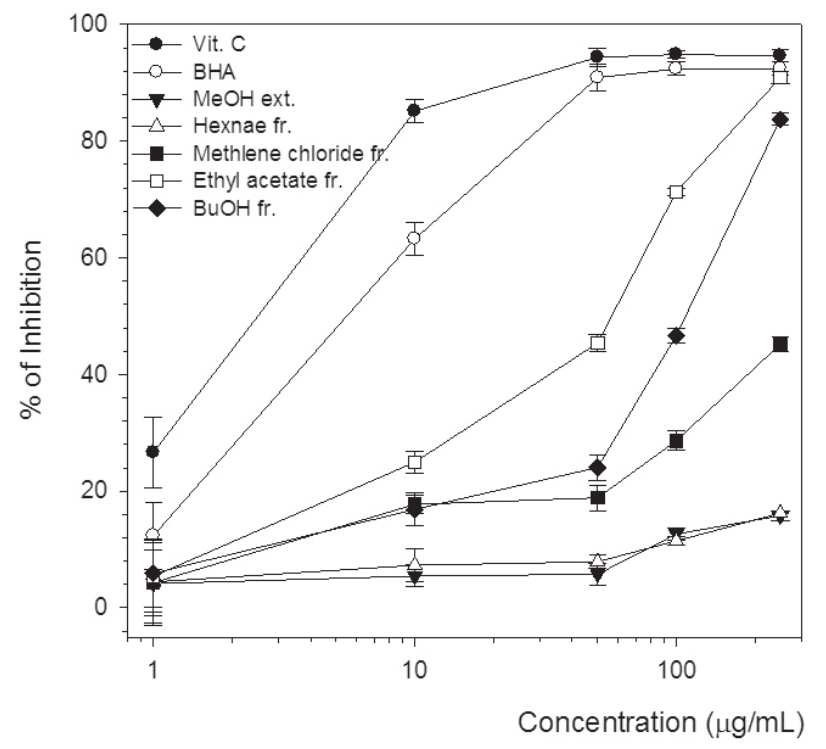

Fig. 1. Scavenging effects of methanol extract and its subsequent fractions from the aerial parts of $G$. spurium on 1,1-diphenyl-2picrylhydrazyl (DPPH) radical. $\mathrm{mg})$. Fraction E4 (210 mg) was chromatographed on silica gel column chromatography $\left(\mathrm{CHCl}_{3}-\mathrm{MeOH}-\mathrm{H}_{2} \mathrm{O}, 40: 10: 1\right)$ to give three subfractions (E41-E43). Subfraction E42 (42 mg) was further chromatographed on a JAI-GS310 cloumn $(\mathrm{MeOH})$ and purified by Sephadex $\mathrm{LH}-20(\mathrm{MeOH})$ to give compound 3 (6 $\mathrm{mg})$. Fraction E5 $(410 \mathrm{mg})$ was chromatographed on silica gel column chromatography $\left(\mathrm{CHCl}_{3}-\mathrm{MeOH}-\mathrm{H}_{2} \mathrm{O}, 20: 10: 1\right)$ to give four subfractions (E51-E54). Subfraction E52 (42 mg) was further chromatographed on a JAI-GS310 cloumn (MeOH) to give compound 4 (8 mg). Subfraction E54 (104 mg) was chromatographed on a JAI-GS310 cloumn (MeOH) to give compound 5 (48 mg). Fraction E6 (230 mg) was chromatographed on silica gel column chromatography $\left(\mathrm{CHCl}_{3}-\mathrm{MeOH}-\mathrm{H}_{2} \mathrm{O}, 30: 10: 1\right)$ to give six subfractions (E61-E66). Subfraction E62 (42 mg) was chromatographed on a JAI-GS310 cloumn (MeOH) to give compound 6 (5 mg). Subfraction E63 $(48 \mathrm{mg})$ was chromatographed on a JAI-GS310 cloumn (MeOH) to give compound 7 (8 mg). Subfraction E65 (62 mg) was applied on a JAI-GS310 cloumn $(\mathrm{MeOH})$ to give compound $8(12 \mathrm{mg})$. Fraction E8 (50 $\mathrm{mg}$ ) was chromatographed on a JAI-GS310 cloumn (MeOH) to give compound 9 (12 $\mathrm{mg}$ ).

\section{Asperulosidic acid methyl ester (1)}

Amorphous powder, ${ }^{1} \mathrm{H}-\mathrm{NMR}\left(400 \mathrm{MHz}, \mathrm{CD}_{3} \mathrm{OD}\right) \delta: 7.61$ $(1 \mathrm{H}, \mathrm{s}, \mathrm{H}-3), 5.98(1 \mathrm{H}, \mathrm{s}, \mathrm{H}-7), 5.02(1 \mathrm{H}, \mathrm{d}, \mathrm{J}=8.8 \mathrm{~Hz}, \mathrm{H}-1)$, $4.68(1 \mathrm{H}, \mathrm{d}, \mathrm{J}=8.0 \mathrm{~Hz}, \mathrm{H}-6), 3.74\left(3 \mathrm{H}, \mathrm{s},-\mathrm{OCH}_{3}\right), 2.99(1 \mathrm{H}$, t, J=6.0 Hz, H-9), $2.60(1 \mathrm{H}, \mathrm{t}, \mathrm{J}=8.4 \mathrm{~Hz}, \mathrm{H}-5), 2.05(3 \mathrm{H}, \mathrm{s}$, $\left.-\mathrm{CH}_{3} \mathrm{COO}\right) .{ }^{13} \mathrm{C}-\mathrm{NMR},\left(100 \mathrm{MHz}, \mathrm{CD}_{3} \mathrm{OD}\right) \delta: 172.5$ (-COO), 169.3 (C-11), 155.4 (C-3), 145.9 (C-8), 131.8 (C-7), 108.0 (C-4), 101.3 (C-1'), 100.6 (C-1), 78.5 (C-3'), 77.8 (C-5'), 75.3 (C-6), 74.9 (C-2'), 71.5 (C-4'), 63.7 (C-10), 62.9 (C-6'), 51.9 $\left(\mathrm{O} \underline{\mathrm{CH}}_{3}\right), 46.2$ (C-9), 42.4 (C-5), $20.8\left(-\underline{\mathrm{CH}}_{3} \mathrm{COO}\right)$.

\section{Asperuloside (2)}

Amorphous powder, ${ }^{1} \mathrm{H}-\mathrm{NMR}\left(400 \mathrm{MHz}, \mathrm{CD}_{3} \mathrm{OD}\right) \delta: 7.29$ $(1 \mathrm{H}, \mathrm{d}, \mathrm{J}=2.0 \mathrm{~Hz}, \mathrm{H}-3), 5.96(1 \mathrm{H}, \mathrm{m}, \mathrm{H}-7), 5.72(1 \mathrm{H}, \mathrm{s}, \mathrm{H}-1)$, $5.57(1 \mathrm{H}, \mathrm{d}, \mathrm{J}=7.2 \mathrm{~Hz}, \mathrm{H}-6), 4.77(2 \mathrm{H}, \mathrm{br} \mathrm{s}, \mathrm{H}-10), 3.67(1 \mathrm{H}$, $\mathrm{m}, \mathrm{H}-9), 3.37(1 \mathrm{H}, \mathrm{m}, \mathrm{H}-5), 2.08(3 \mathrm{H}, \mathrm{s},-\underline{\mathrm{CH}} 3) .{ }^{13} \mathrm{C}-\mathrm{NMR}$ (100 MHz, CD ${ }_{3}$ OD) $\delta: 172.6$ (-COO), 172.2 (C-11), 150.3 (C3), 144.3 (C-8), 128.9 (C-7), 106.2 (C-4), 100.0 (C-1), 93.3 (C-1'), 86.3 (C-6), 78.3 (C-3'), 77.9 (C-5'), 74.6 (C-2'), 71.6 (C-4'), 62.8 (C-10), 61.9 (C-6'), 45.3 (C-9), 37.4 (C-5), 20.6 $\left(-\underline{\mathrm{C}} \mathrm{H}_{3} \mathrm{COO}\right)$.

\section{Caffeic acid (3)}

Yellowish amorphous solid, ${ }^{1} \mathrm{H}-\mathrm{NMR}\left(400 \mathrm{MHz}, \mathrm{CD}_{3} \mathrm{OD}\right)$ $\delta: 7.56(1 \mathrm{H}, \mathrm{d}, J=16.0 \mathrm{~Hz}, \mathrm{H}-7), 7.04(1 \mathrm{H}, \mathrm{d}, J=2.0 \mathrm{~Hz}, \mathrm{H}-2)$, $6.94(1 \mathrm{H}, \mathrm{dd}, J=8.4,2.2 \mathrm{~Hz}, \mathrm{H}-6), 6.77(1 \mathrm{H}, \mathrm{d}, J=7.6 \mathrm{~Hz}, \mathrm{H}-5)$, $6.27(1 \mathrm{H}, \mathrm{d}, \mathrm{J}=16.0 \mathrm{~Hz}, \mathrm{H}-8) .{ }^{13} \mathrm{C}-\mathrm{NMR}\left(100 \mathrm{MHz}, \mathrm{CD}_{3} \mathrm{OD}\right) \delta$ : 169.0 (C-9), 149.5 (C-4), 146.9 (C-7), 146.8 (C-3), 127.8 (C1), 122.9 (C-6), 116.5 (C-5), 115.5 (C-8), 115.2 (C-2).

\section{Kaempferol-3-0-L-rhamnopyranoside (4)}

Yellowish powder, ${ }^{1} \mathrm{H}-\mathrm{NMR}\left(400 \mathrm{MHz}, \mathrm{CD}_{3} \mathrm{OD}\right) \delta: 7.74(2 \mathrm{H}$, d, J=8.8 Hz, H-2', 6'), $6.91\left(2 \mathrm{H}, \mathrm{d}, \mathrm{J}=8.8 \mathrm{~Hz}, \mathrm{H}^{3} 3^{\prime}, 5^{\prime}\right), 6.34(1 \mathrm{H}$, d, $J=2.0 \mathrm{~Hz}, \mathrm{H}-8), 6.17(1 \mathrm{H}, \mathrm{d}, J=2.0 \mathrm{~Hz}, \mathrm{H}-6), 5.36(1 \mathrm{H}, \mathrm{d}$, $J=1.4 \mathrm{~Hz}, \mathrm{H}-1 "), 3.33(1 \mathrm{H}, \mathrm{dd}, J=5.2,1.2 \mathrm{~Hz}, \mathrm{H}-4$ ") $0.92(3 \mathrm{H}, \mathrm{d}$, $\mathrm{J}=5.6 \mathrm{~Hz}, \mathrm{H}-6 ") .{ }^{13} \mathrm{C}-\mathrm{NMR}\left(100 \mathrm{MHz}, \mathrm{CD}_{3} \mathrm{OD}\right)$ : Table 1.

\section{Quercetin-3-0-[a-L-rhamnopyranosyl $(1 \rightarrow 6)-\beta$-D- glucopyranoside] (5)}

Yellowish powder, ${ }^{1} \mathrm{H}-\mathrm{NMR}\left(400 \mathrm{MHz}, \mathrm{CD}_{3} \mathrm{OD}\right) \delta: 7.66(1 \mathrm{H}$, 
Table 1. ${ }^{13} \mathrm{C}$-NMR spectral data of compounds $4-9$

\begin{tabular}{|c|c|c|c|c|c|c|}
\hline C & $4^{a}$ & $5^{\mathrm{a}}$ & $6^{a}$ & $7^{a}$ & $8^{b}$ & $9^{b}$ \\
\hline 2 & 158.5 & 158.5 & 158.7 & 149.7 & 154.4 & 147.6 \\
\hline 3 & 136.2 & 135.6 & 135.3 & 136.2 & 133.4 & 135.7 \\
\hline 4 & 179.5 & 179.4 & 179.4 & 179.5 & 177.5 & 175.8 \\
\hline 5 & 163.1 & 163.1 & 163.1 & 163.0 & 160.8 & 160.7 \\
\hline 6 & 99.8 & 100.0 & 99.9 & 99.9 & 98.8 & 98.1 \\
\hline 7 & 165.8 & 166.1 & 166.0 & 165.7 & 164.1 & 163.8 \\
\hline 8 & 94.8 & 94.8 & 94.7 & 94.7 & 94.0 & 93.3 \\
\hline 9 & 159.2 & 159.4 & 158.5 & 158.4 & 156.9 & 156.1 \\
\hline 10 & 105.9 & 105.7 & 105.8 & 105.8 & 104.1 & 103.0 \\
\hline $1^{\prime}$ & 122.6 & 123.1 & 123.1 & 122.9 & 121.2 & 121.9 \\
\hline $2^{\prime}$ & 131.9 & 116.1 & 114.3 & 117.0 & 131.1 & 115.0 \\
\hline $3^{\prime}$ & 116.5 & 145.9 & 148.4 & 146.3 & 115.3 & 146.7 \\
\hline $4^{\prime}$ & 161.5 & 149.8 & 150.9 & 159.2 & 159.7 & 145.0 \\
\hline $5^{\prime}$ & 116.5 & 117.7 & 116.0 & 116.3 & 115.3 & 115.5 \\
\hline $6^{\prime}$ & 131.9 & 123.6 & 123.8 & 122.8 & 131.1 & 119.9 \\
\hline $1 "$ & 103.5 & 104.7 & 103.6 & 103.5 & 101.4 & \\
\hline 2" & 72.0 & 75.7 & 75.9 & 71.9 & 74.4 & \\
\hline 3" & 72.1 & 78.2 & 78.6 & 72.1 & 76.5 & \\
\hline 4" & 73.2 & 71.4 & 71.5 & 73.2 & 70.7 & \\
\hline 5" & 71.9 & 77.2 & 78.1 & 72.0 & 75.8 & \\
\hline 6" & 17.6 & 68.6 & 62.5 & 17.6 & 67.0 & \\
\hline $1 " '$ & & 102.4 & & & 101.0 & \\
\hline 2"' & & 72.1 & & & 70.5 & \\
\hline 3"' & & 72.2 & & & 70.0 & \\
\hline 4"' & & 73.9 & & & 71.6 & \\
\hline 5"' & & 69.7 & & & 68.5 & \\
\hline 6"' & & 17.9 & & & 17.8 & \\
\hline $\mathrm{OCH}_{3}$ & & & 56.8 & & & \\
\hline
\end{tabular}

Recorded at $100 \mathrm{MHz}$ in $\mathrm{CD}_{3} \mathrm{OD},{ }^{\mathrm{b}}$ Recorded at $100 \mathrm{MHz}$ in DMSO- $d_{6}$

d, J=1.6 Hz, H-2'), $7.61\left(1 \mathrm{H}, \mathrm{dd}, J=8.4,2.0 \mathrm{~Hz}, \mathrm{H}-6^{\prime}\right), 6.86(1 \mathrm{H}$, d, $\left.J=8.0 \mathrm{~Hz}, \mathrm{H}-5^{\prime}\right), 6.39(1 \mathrm{H}, \mathrm{d}, J=2.0, \mathrm{H}-8), 6.20(1 \mathrm{H}, \mathrm{d}, J=2.0$ $\mathrm{Hz}, \mathrm{H}-6), 5.09(1 \mathrm{H}, \mathrm{d}, \mathrm{J}=7.6 \mathrm{~Hz}, \mathrm{H}-1 ")$, 4.51 (1H, br s, H-1"'), $1.11\left(3 \mathrm{H}, \mathrm{d}, \mathrm{J}=6.0 \mathrm{~Hz}, \mathrm{H}-6 \mathrm{C}^{\prime \prime}\right) .{ }^{13} \mathrm{C}-\mathrm{NMR}\left(100 \mathrm{MHz}, \mathrm{CD}_{3} \mathrm{OD}\right)$ : Table 1 .

\section{Isorhamnetin-3-0-glucopyranoside (6)}

Yellowish amorphous powder, ${ }^{1} \mathrm{H}-\mathrm{NMR}\left(400 \mathrm{MHz}, \mathrm{CD}_{3} \mathrm{OD}\right)$ $\delta: 7.83\left(1 \mathrm{H}, \mathrm{d}, \mathrm{J}=2.0 \mathrm{H}-2^{\prime}\right), 7.49\left(1 \mathrm{H}, \mathrm{dd}, J=28.4,2.0 \mathrm{~Hz}, \mathrm{H}^{\prime} 6^{\prime}\right)$, $6.79\left(1 \mathrm{H}, \mathrm{d}, J=28.4 \mathrm{~Hz}, \mathrm{H}-5^{\prime}\right), 6.30(1 \mathrm{H}, \mathrm{d}, J=22.0, \mathrm{H}-8), 6.11$ $(1 \mathrm{H}, \mathrm{d}, J=22.0 \mathrm{~Hz}, \mathrm{H}-6), 5.32(1 \mathrm{H}, \mathrm{d}, J=27.6 \mathrm{~Hz}$, glc anomeric $\mathrm{H}), 3.85\left(3 \mathrm{H}, \mathrm{s},-\mathrm{OCH}_{3}\right) .13 \mathrm{C}-\mathrm{NMR}\left(100 \mathrm{MHz}, \mathrm{CD}_{3} \mathrm{OD}\right)$ : Table 1.

\section{Quercetin-3-0-a-L-rhamnopyranoside (7)}

Yellow amorphous powder, ${ }^{1} \mathrm{H}-\mathrm{NMR}\left(400 \mathrm{MHz}, \mathrm{CD}_{3} \mathrm{OD}\right) \delta$ : $7.29\left(1 \mathrm{H}, \mathrm{s}, \mathrm{H}-2^{\prime}\right), 7.25\left(1 \mathrm{H}, \mathrm{d}, J=7.6 \mathrm{~Hz}, \mathrm{H}-6{ }^{\prime}\right), 6.86(1 \mathrm{H}, \mathrm{d}$, $\left.J=8.4 \mathrm{~Hz}, \mathrm{H}-5^{\prime}\right), 6.29(1 \mathrm{H}, \mathrm{d}, J=1.8 \mathrm{~Hz}, \mathrm{H}-8), 6.13(1 \mathrm{H}, \mathrm{d}, J=1.8$ $\mathrm{Hz}, \mathrm{H}-6), 5.30(1 \mathrm{H}, \mathrm{d}, \mathrm{J}=1.0 \mathrm{H}-1 "), 4.19(1 \mathrm{H}, \mathrm{s}, \mathrm{H}-2 "), 3.72$ $(1 \mathrm{H}, \mathrm{d}, \mathrm{J}=6.7 \mathrm{~Hz}, \mathrm{H}-3 "), 3.36(1 \mathrm{H}, \mathrm{m}, \mathrm{H}-5 ")$, $3.34(1 \mathrm{H}, \mathrm{d}, \mathrm{J}=9.2$ $\mathrm{Hz}, \mathrm{H}-4 "), 0.90(3 \mathrm{H}, \mathrm{d}, \mathrm{J}=6.1 \mathrm{~Hz}, \mathrm{H}-6 ") .{ }^{13} \mathrm{C}-\mathrm{NMR}(100 \mathrm{MHz}$, $\left.\mathrm{CD}_{3} \mathrm{OD}\right)$ : Table 1.

\section{Kaempferol-3-0-[a-L-rhamnopyranosyl (1 $\rightarrow 6)-\beta$-D- glucopyranoside) (8)}

Yellowish powder, ${ }^{1} \mathrm{H}-\mathrm{NMR}\left(400 \mathrm{MHz}, \mathrm{DMSO}-d_{6}\right) \delta: 7.97$ $\left(2 \mathrm{H}, \mathrm{d}, \mathrm{J}=8.8 \mathrm{~Hz}, \mathrm{H}-2^{\prime}, 6^{\prime}\right), 6.79\left(2 \mathrm{H}, \mathrm{d}, J=8.8 \mathrm{~Hz}, \mathrm{H}-3^{\prime}, 5^{\prime}\right)$, $6.43(1 \mathrm{H}, \mathrm{d}, \mathrm{J}=2.0 \mathrm{~Hz}, \mathrm{H}-8), 6.24(1 \mathrm{H}, \mathrm{d}, \mathrm{J}=2.0 \mathrm{~Hz}, \mathrm{H}-6), 5.00$ $(1 \mathrm{H}, \mathrm{d}, \mathrm{J}=7.0 \mathrm{~Hz}, \mathrm{H}-1 "), 4.41$ (1H, brs, $\left.\mathrm{H}-1{ }^{\prime \prime \prime}\right) .{ }^{13} \mathrm{C}-\mathrm{NMR}(100$ $\left.\mathrm{MHz}, \mathrm{DMSO}-d_{6}\right)$ : Table 1.

\section{Quercetin (9)}

Yellowish powder, ${ }^{1} \mathrm{H}-\mathrm{NMR}\left(400 \mathrm{MHz}\right.$, DMSO- $\left.d_{6}\right) \delta: 7.68$ $\left(1 \mathrm{H}, \mathrm{d}, J=2.4 \mathrm{~Hz}, \mathrm{H}-2^{\prime}\right), 7.54\left(1 \mathrm{H}, \mathrm{dd}, J=8.0,2.0 \mathrm{~Hz}, \mathrm{H}^{6}-6^{\prime}\right), 6.89$ $\left(1 \mathrm{H}, \mathrm{d}, J=8.4 \mathrm{~Hz}, \mathrm{H}-5^{\prime}\right), 6.41(1 \mathrm{H}, \mathrm{d}, J=2.0 \mathrm{~Hz}, \mathrm{H}-8), 6.19(1 \mathrm{H}$, d, $J=2.0 \mathrm{~Hz}, \mathrm{H}-6) .{ }^{13} \mathrm{C}-\mathrm{NMR}\left(100 \mathrm{MHz}\right.$, DMSO- $\left.d_{6}\right)$ : Table 1.

\section{DPPH radical scavenging effect}

Ethanol solutions of test samples at various concentrations $(0.1-100 \mu \mathrm{g} / \mathrm{ml})$ were added to a solution of DPPH in ethanol $\left(1.5 \times 10^{-4} \mathrm{M}\right)$ in 96 well plates. After storing these mixtures for 30 minutes at room temperature, the remaining amounts of DPPH were determined by colorimetry at $520 \mathrm{~nm}$ on a microplate reader (Yoshida et al., 1989). And the radical scavenging activity of each compound was expressed by the ratio of the lowering of the DPPH solution in the absence of compounds. The mean values were obtained from triplicate experiments.

\section{Superoxide quenching activity}

Superoxide quenching activities of test samples were measured photochemically, using an assay system consisting of methionine, riboflavin, and nitrobluetetrazolium (NBT) (Ginnopolitis and Ries, 1977; Choi et al., 2001). The reaction mixture was composed of $2.6 \mu \mathrm{M}$ riboflavin, $13 \mathrm{mM}$ methionine, $75 \mu \mathrm{M}$ NBT, $0.1 \mathrm{mM}$ EDTA, $0.05 \mathrm{M}$ sodium phosphate $(\mathrm{pH}$ 7.8 ), and various concentrations of test samples. The sample was randomly placed in a light storage box and replaced randomly every $5 \mathrm{~min}$ for $15 \mathrm{~min}$. The temperature within the light storage box was $20 \pm 1^{\circ} \mathrm{C}$ during the light illumination. The light intensity at the sample level was 5,500 lux. NBT was reduced to blue formazan formation during the light illumination, and that was measured by the absorbance at $560 \mathrm{~nm}$. The inhibition of blue formazan formation was taken as superoxide quenching activity.

\section{RESULTS AND DISCUSSION}

In the course of our screening for antioxidative components from Korean natural plants, the ethyl acetate soluble fraction of methanolic extract of the aerial parts of G. spurium was found to show scavenging activity on DPPH radical (Fig. 1). Subsequent activity-guided fractionation of the ethyl acetate soluble fraction led to the isolation of two iridoid glycosides, six flavonoids and a phenylpropanoid (Fig. 2).

The ${ }^{1} \mathrm{H}-\mathrm{NMR}$ spectrum of compound 1 showed a methoxy signal at a $\delta 3.74(3 \mathrm{H}, \mathrm{s})$, doublet at $\delta 7.61(1 \mathrm{H}, \mathrm{s})$ which was assigned to the enol ether proton at $\mathrm{C}-3$ and the triplet at $\delta$ $2.60(1 \mathrm{H}, \mathrm{t}, J=8.4 \mathrm{~Hz})$ and $2.99(1 \mathrm{H}, \mathrm{t}, J=6.0 \mathrm{~Hz})$ were assigned to the protons at C-5 and C-9. In the ${ }^{13} \mathrm{C}-\mathrm{NMR}$ spectrum, 19 carbon signals were observed, which included two carbonyl groups at $\delta 172.5$ and 169.3 , four olefinic carbons at $\delta 155.4,145.9,131.8$ and 108.0, six sugar carbons at $\delta 101.3$, $78.5,77.8,74.9,71.5$ and 62.9 , and a methyl group at $\delta 20.8$. From these results, compound 1 was indicated to be a iridoid 


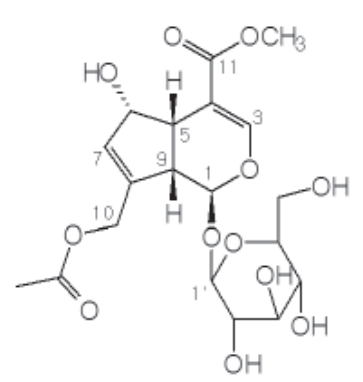

1

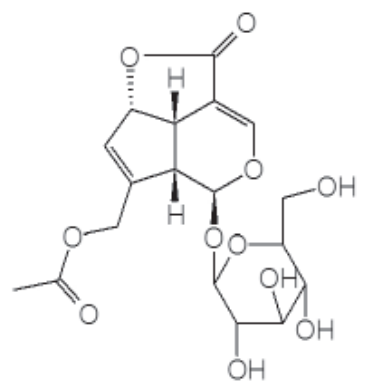

2<smiles>O=C(O)/C=C/c1ccc(O)c(O)c1</smiles>

3<smiles>[R]c1cc(-c2oc3cc(O)cc(O)c3c(=O)c2OC)ccc1O</smiles>

$\mathrm{R}_{1}$

$\mathrm{R}_{2}$

4 Rhamnose $\mathrm{H}$

5 Rutinose $\mathrm{OH}$

6 Glucose $\mathrm{OCH}_{3}$

7 Rhamnose $\mathrm{OH}$

8 Rutinose $\mathrm{H}$

$9 \mathrm{H} \quad \mathrm{OH}$ Fig. 2. Structures of compounds 1-9 isolated from G. spurium.

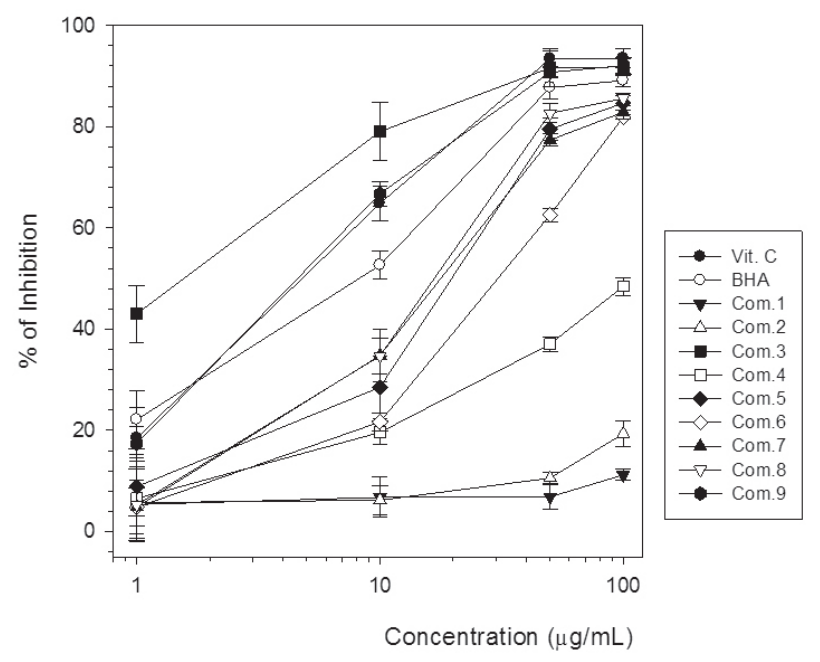

Fig. 3. Scavenging effects of compounds 1-9 from the ethyl acetate soluble fraction of $G$. spurium on 1,1-diphenyl-2-picrylhydrazyl (DPPH) radical.

glycoside. The structure of 1 was determined to be asperulosidic acid methyl ester on the basis of the above evidences, together with a comparison of the above data with those published in the literature (El-Naggar and Beal, 1980; Takeda et al., 2002). The ${ }^{1} \mathrm{H}-\mathrm{NMR}$ spectrum of 2 showed a doublet at $\delta$ $7.29(1 \mathrm{H}, \mathrm{d}, \mathrm{J}=2.0 \mathrm{~Hz})$ which was assigned to the enol ether

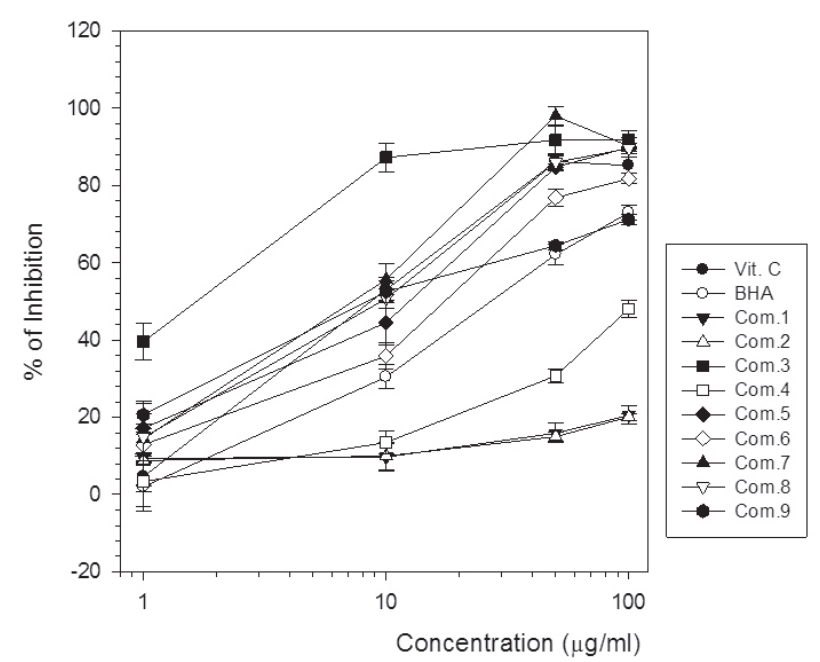

Fig. 4. Superoxide quenching activities of compounds 1-9 from the ethyl acetate soluble fraction of $G$. spurium.

proton at $\mathrm{C}-3$, and the multiplet at $\delta 3.37(1 \mathrm{H}, \mathrm{m})$ and $3.67(1 \mathrm{H}$, $\mathrm{m})$, were assigned to the protons at $\mathrm{C}-5$ and $\mathrm{C}-9$. In the ${ }^{13} \mathrm{C}$ NMR spectrum, 18 carbon signals were observed, which included two carbonyl groups at $\delta 172.6$ and 172.2 , four olefinic carbons at $\delta 150.3,144.3,128.9$ and 106.2, six sugar carbons at $\delta 93.3,78.377 .9,74.6,71.6$ and 61.9 , and a methyl group at $\delta$ 20.6. From these results, compound 2 was indicated to be 
an iridoid glycoside. The structure of 2 was determined to be asperuloside on the basis of the above evidences, together with a comparison of the above data with those published in the literature (El-Naggar and Beal, 1980; Lee et al., 2004). Compound 3 was isolated as a yellowish amorphous solid and positive to $\mathrm{FeCl} 3$ reagent test. In the ${ }^{1} \mathrm{H}-\mathrm{NMR}$ spectrum, two olefinic protons having trans-configuration were observed at $\delta$ $7.56(1 \mathrm{H}, \mathrm{d}, \mathrm{J}=16.0 \mathrm{~Hz}, \mathrm{H}-7)$ and $6.27(1 \mathrm{H}, \mathrm{d}, \mathrm{J}=16.0 \mathrm{~Hz}, \mathrm{H}-8)$. Typical signals for 1,3,4-trisubsituted benzene were detected at $\delta 7.04(1 \mathrm{H}, \mathrm{d}, J=2.0 \mathrm{~Hz}, \mathrm{H}-2), 6.94(1 \mathrm{H}, \mathrm{dd}, J=8.4,2.2 \mathrm{~Hz}$, $\mathrm{H}-6)$ and $6.77(1 \mathrm{H}, \mathrm{d}, J=7.6 \mathrm{~Hz}, \mathrm{H}-5)$. In the ${ }^{13} \mathrm{C}-\mathrm{NMR}$ spectrum, 9 carbons were detected including a carbonyl carbon at $\delta$ 169.0. On the basis of these observations and the comparision of the data with those previously published, the structure of compound 3 was identified as caffeic acid (Wu et al., 1999).

Compounds 4-9 showed the positive reaction on $\mathrm{Mg}-\mathrm{HCl}$ tests, and have similar patterns in their NMR spectra. Compounds 4-9 were deduced to be flavonoids. Structure characterization of these compounds was carried out by interpretation of their spectral data and comparison with the data reported in the literature. Compounds 4-9 were identified as kaempferol-3-O-L-rhamnopyranoside (4) [Hur et al., 2001; Jang et al., 2002], quercetin-3-O-[ $\alpha$-L-rhamnopyranosyl( $1 \rightarrow 6)$ $\beta$-D-glucopyranoside] (5) [Kim et al., 1992; Hasan et al., 1995], isorhamnetin-3-O-glucopyranoside (6) [Kim et al., 1998], quercetin-3-O- $\alpha$-L-rhamnopyranoside (7) [Lee et al., 2007], kaempferol-3-O-[ $\alpha$-L-rhamnopyranosyl $(1 \rightarrow 6)$ - $\beta$-D-glucopyranoside] (8) [Hong et al., 2008], and quercetin (9) [Ternai and Markham 1976; Lee et al., 1997; Lee et al., 2007], respectively.

The DPPH radical scavenging effect of the methanolic extract and its solvent partitioned fractions from $G$. spurium are shown in Fig. 1. The positive control vitamin $C$ showed the $\mathrm{DPPH}$ radical scavenging effect with the $\mathrm{IC}_{50}$ value of $4.7 \mu \mathrm{g} /$ $\mathrm{ml}$. Compounds 3 and 9 exhibited scavenging activities dosedependently on DPPH with $\mathrm{IC}_{50}$ values of 1.5 and $4.6 \mu \mathrm{g} / \mathrm{ml}$, respectively (Fig. 3). However, compounds 1 and 2 showed no activities in comparison with reference antioxidants such as ascorbic acid and BHA. Fig. 4 shows the superoxide quenching activities of the isolated compounds $1-9$, as measured by the riboflavin-NBT-light system. The positive control vitamin $C$ showed the superoxide quenching activity with the $I C_{50}$ value of $7.8 \mu \mathrm{g} / \mathrm{ml}$. Whereas, compounds 3 and 7 exhibited superoxide quenching activities dose-dependently on the riboflavin-NBT-light system with $I_{50}$ values of 1.7 and $6.9 \mu \mathrm{g} /$ $\mathrm{ml}$, respectively. Compounds 1 and 2 showed no activities in comparison with reference antioxidants (Fig. 4).

It was reported that compound 3 , caffeic acid has protective effects on chemical-induced hepatotoxicity in rodents, $\beta$-amyloid-induced neurotoxicity and neuronal damage in mouse brain (Janbaz et al., 2004; Zhang et al., 2007; Sul et al., 2009). Recently, Compound 7, quercetin-3-O- $\alpha$-L-rhamnopyranoside was reported the protective effect against hydrogen peroxideinduced dysfunction in osteoblastic MC3T3-E1 cells (Choi, 2010), and lipid peroxidation (Wagner et al., 2006). It was reported that compound 3 , quercetin has protective effects on rat liver against lead-induced oxidative stress and apoptosis, and kidney against oxidative stress-mediated DNA damage and apoptosis induced by lead (Liu et al., 2010a; 2010b). The results from free radical scavenging effects and superoxide quenching activities revealed that the ethyl acetate soluble fraction of G. spurium, and isolated compounds 3, 7 and 9 may be useful for the treatment of various oxidative damage.

\section{ACKNOWLEDGMENTS}

This work was supported by the Grant of the Korean Ministry of Education, Science and Technology (The Regional Core Research Program/Center for Healthcare Technology Development), and also supported by Woosuk University.

\section{REFERENCES}

Branen, A. L. (1975) Toxicology and biochemistry of butylated hydroxyanisole and butylated hydroxytoluene. J. Am. Oil. Chem. Soc. 52, 59-63.

Cai, X., Yang, J. and Rao, Q. (2009) Studies on flavonoids from Galium aparine. Chin. Pharm. J. 44, 1475-1477.

Choi, D. S., Kim, S. J. and Jung, M. Y. (2001) Inhibitory activity of berberine on DNA strand cleavage induced by hydrogen peroxide and cytochrome c. Biosci. Biotechnol. Biochem. 65, 452-455.

Choi, E. M. (2010) Protective effect of quercitrin against hydrogen peroxide-induced dysfunction in osteoblastic MC3T3-E1 cells. Exp. Toxicol. Pathol. in press.

Chung, Y. C., Chen S. J., Hsu, C. K., Chang, C. T. and Chou, S. T. (2005) Studies on the antioxidative activity of Graptopetalum paraguayense E. Walther. Food Chemistry 91, 419-424.

Deliorman, D., Calis, I. and Ergun, F. (2001) Iridoids from Galium aparine. Pharm. biol. 39, 234-235.

El-Naggar, L. J. and Beal, J. L. (1980) Iridoids. A review. J. Nat. Prod. 43, 649-706.

Ginnopolitis, C. N. and Ries, S. K. (1977) Superoxide dismutase. I. Occurrence in higher plants. Plant Physiol. 59, 309-314.

Hasan, A., Anme, K., Jay, M. and Voirin, V. (1995) Flavonoid glycosides and anthraquinone from Rumex chalepensis. Phytochemistry 39, 1211-1213.

Hong, H. K., Kwak, J. H., Kang, S. C., Lee, J. W., Park, J. H., Ahn, J. W., Kang, H. S., Choung, E. S. and Zee, O. P. (2008) Antioxidative constituents from the whole plants of Euphorbia supina. Korean J. Pharmacogn. 39, 260-264.

Hur, J. M., Park, J. C. and Hwang, Y. H. (2001) Aromatic acid and flavonoids from the leaves of Zanthoxylum piperitum. Nat. Prod. Sci. 7, 23-26.

Janbaz, K. H., Saeed, S. A. and Gilani, A. H. (2004) Studies on the protective effects of caffeic acid and quercetin on chemical-induced hepatotoxicity in rodents. Phytomedicine 5, 424-430.

Jang, K. G., Oh, H., Ko, E. K., Kang, K. H., Park, S. E., Oh, M. H. and Kim, Y. C. (2002) Free radical scavengers from the leaves of Albizzia julibrissin. Korean J. Pharmacogn. 33, 28-30.

Kim, H. K., Kang, B. J., Park, K. J., Ko, B. S. and Whang, W. K. (1998) Anti-Herpes simplex virus type 1 (HSV-1) effect of isorhamnetin 3-O- $\beta$-D-glucopyranoside isolated from Brassica rapa. J. Pharm. Soc. Korea 42, 607-612.

Kim, S. H., Hwang, K. T. and Park, J. C. (1992) Isolation of flavonoids and determination of rutin from the leaves of Ulmus parviflora. Korean J. Pharmacogn. 23, 229-233.

Koyama, J., Ogura, T. and Tagahra, K. (1993) Anthraquinones of Galium spurium. Phytochemistry 33, 1540-1542.

Lee, H. J., Lee, S. K., Choi, Y. J., Jo, H. J., Kang, H. Y. and Choi, D. H. (2007) Extractives from the bark of Platycarya strobilacea. Journal of Korean Forest Society 96, 408-413.

Lee, J. H., Ku, C. H., Baek, N. I., Kim, S. H., Park, H. W. and Kim, D. K. (2004) Phytochemical constituents from Diodia teres. Arch. Pharm. Res. 27, 40-43.

Lee, S. K., Park, W. G. and Bae, Y. S. (1997) Procyanidins from Lindera obtusiloba bark. Mokchae konghak 25, 110-116.

Liu, C. M., Ma, J. Q. and Sun, Y. Z. (2010a) Quercetin protects the rat kidney against oxidative stress-mediated DNA damage and apoptosis induced by lead. Environ. Toxicol. Pharmacol. 30, 264-271.

Liu, C. M., Zheng, Y. L., Lu, J., Zhang, Z. F., Fan, S. H., Wu, D. M. and 
Ma, J. Q. (2010b) Quercetin protects rat liver against lead-induced oxidative stress and apoptosis. Environ. Toxicol. Pharmacol. 29, 158-166.

Monika, L. L., Zbigniew, S. and Halina, B. P. (2010) Influencn of vitamin $\mathrm{C}$ on markers of oxidative stress in the earliest period of ischemic stroke. Pharmacol. Rep. 62, 751-756.

Salvatore, R., Carmine, I., Maya, M., Nedjalka H., Simeon, P. and Mincho, A. (2000) Triterpene saponins and iridoid glucosides from Galium rivale. Phytochemistry 54, 751-756.

Suganya, T., Siriporn, O. and Sombat C. (2007) Studies on antioxidative activity of certain plants in Thailand: Mechanism of antioxidant action of guava leaf extract. Food Chemistry 103, 381-388.

Sul, D., Kim, H. S., Lee, D., Joo, S. S., Hwang, K. W. and Park, S. Y. (2009) Protective effect of caffeic acid against beta-amyloidinduced neurotoxicity by the inhibition of calcium influx and tau phosphorylation. Life Sci. 84, 257-262.

Takeda, Y., Shimidzu, H., Mizuno, K., Inouchi S., Masuda, T., Hirata, E., Shinzato, T., Aramoto, M. and Otsuka, H. (2002) An iridoid glucoside dimer and non-glycosidic iridoid from the leaves of Lasianthus wallichii. Chem. Pharm. Bull. 50 1395-1397.
Ternai, B. and Markham, K. R. (1976) Carbon-13 NMR studies of flavonoids-I: flavones and flavonols. Tetrahedron 32, 565-569.

Wagner, C., Fachinetto, R., Dalla, C. C. L., Brito, V. B., Severo, D. de Oliveira, C. D. G., Morel, A. F., Nogueira, C. W. and Rocha, J. B. (2006) Quercitrin, a glycoside form of quercetin, prevents lipid peroxidation in vitro. Brain Res. 1107, 192-198.

Wu, Z. J., Ouyang, M. A. and Yang, C. R. (1999) Polyphenolic constituents of Salvia onchifolia. Acta Bot. Yunnan 21, 393-398.

Yoon, T. J., Lee, C. K., Park, T. K. and Lee, K. H. (2005) Immunostimulant and anti-tumor activity of crude extracts of Galium aparine L. Korean J. Pharmacogn. 36, 332-337.

Yoshida, T., Mori, K., Hatano, T., Okumura, T., Uehara, L., Komagoe, K., Fujita, Y. and Okuda, T. (1989) Studies on inhibition mechanism of autooxidation by tannins and flavonoids. V. Radical scavenging effects of tannins and related polyphenols on 1,1-diphenyl-2-picrylhydrazyl radical. Chem. Pharm. Bull. 37, 1919-1921.

Zhang, L., Zhang, W. P., Chen, K. D., Qian, X. D. Fang, S. H. and Wei, E. Q. (2007) Caffeic acid attenuates neuronal damage, astrogliosis and glial scar formation in mouse brain with cryoinjury. Life Sci. 80, 530-537. 